\author{
EDWARD OPALIŃSKI \\ Instytut Historii PAN, Warszawa \\ Uniwersytet Jana Kochanowskiego w Kielcach, \\ Filia $w$ Piotrkowie Trybunalskim
}

\title{
ZYGMUNT III WOBEC HABSBURGÓW I JANA ZAMOYSKIEGO*
}

Abstrakt: Artykuł recenzyjny dotyczy monografii Przemysława Szpaczyńskiego o mocarstwowych dążeniach króla Zygmunta III. Monarcha ten był władcą Polski w okresie 1587-1632 oraz władał Szwecją od 1592 do 1599, kiedy został przez Szwedów zdetronizowany. Ocenie poddano przede wszystkim relacje króla z Habsburgami i opozycją wewnętrzną w latach 1587-1592.

Słowa kluczowe: Zygmunt III, Habsburgowie, Jan Zamoyski, arcyksiążę Ernest, Karol, książę sudermański.
Abstract: Sigismund (Zygmunt) III Vasa was the ruler of Poland in 1587-1632 and of Sweden from 1592 to 1599 , that is, until his dethronement by the Swedes. This article mainly assesses the relations between the Sigismund and the Habsburgs and the domestic opposition in the years 1587-1592 in the light of theses and findings by Przemysław Szpaczyński.

Keywords: Sigismund III, Habsburgs, Jan Zamoyski, Archduke Ernest, Duke Charles of Södermanland (Charles IX of Sweden).

Monografia Przemysława Szpaczyńskiego poświęcona mocarstwowym dążeniom pierwszego na tronie polskim Jagiellona po kądzieli obejmuje lata 15871618. Praca ma układ rzeczowo-chronologiczny. Składa się z czterech rozdziałów, wstępu i zakończenia. Zawiera ponadto wykaz źródeł i literatury przedmiotu oraz indeks osobowy.

We wstępie Autor przedstawia cel badawczy, jakim jest: „ukazanie mocarstwowych dążeń Zygmunta III w latach 1587-1618 oraz wykazanie m.in., jakie znaczenie dla ich realizacji miała polityka króla wobec Habsburgów austriackich" (s. 9). „Data końcowa - 1618 r. - stanowi punkt zwrotny w mocarstwowych

* Na marginesie: Przemysław Szpaczyński, Mocarstwowe dążenia Zygmunta III w latach 1587-1618, Kraków 2013, Universitas, ss. 414. 
dążeniach Zygmunta III poprzez fakt, iż oznacza kres możliwości zrealizowania ich przy pomocy Rzeczypospolitej. Odtąd król będzie usiłował forsować swe plany w oparciu o układy z Habsburgami, wykorzystując szansę, jaką stworzy ku temu wojna trzydziestoletnia (1618-1648)" (s. 9). Datę końcową można zaakceptować, gdyż kończyła ona etap walk polsko-moskiewskich. Jednak argumentacja P. Szpaczyńskiego dla jej przyjęcia budzi pewne opory, gdyż podczas walk z Turcją monarcha próbował wciągnąć do działań militarnych nie tylko Habsburgów, ale i połowę Europy, pomoc zaś militarna Habsburgów miała miejsce jedynie pod koniec walk ze Szwedami. Natomiast przy zawarciu rozejmu w Starej Wsi mediacja austriacka nie odegrała żadnej roli.

Autor ma również drugi cel. Jest nim niewątpliwie walka z negatywnym stereotypem Zygmunta III, dominującym, jego zdaniem, w historiografii. Trzeba przyznać, że realizuje go bardzo gorliwie, tak, że momentami monografia sprawia wrażenie hagiografii.

P. Szpaczyński opowiada się za nieużywaniem przydomku Waza w stosunku do Zygmunta III i jego synów. Uważa, i słusznie, że to Jagiellonowie po kądzieli. $\mathrm{Z}$ tą propozycją można sympatyzować, choć z drugiej strony warto zauważyć, że przydomek Wazowie podkreśla ciągłość panowania tej swoistej dynastii w monarchii elekcyjnej.

Baza źródłowa pracy jest niewątpliwie obszerna, choć Autor nie zna kilku ważnych edycji źródłowych, związanych z działalnością dyplomacji papieskiej. Wymienić tu można Annibale di Capua. Materiali per una biografia, wydane przez Jana Władysława Wosia (Roma 1984). Co prawda w bibliografii zamieszczono Die Hauptinstruktionen Clemens' VIII. für die Nuntien und Legaten an den europäischen Fürstenhöfen 1592-1605, wydane przez Karla Jaitnera, jednak ani razu nie powołano się na nie, choć zawierają interesujące materiały tak do problemu ligi antytureckiej, jak i stosunku króla do Szwecji i Habsburgów ${ }^{1}$. Jeśli chodzi o rękopisy, to trzeba podkreślić, że wykorzystano wyłącznie zasoby polskich bibliotek i archiwów. Dziwi więc w kontekście tematyki pracy brak archiwaliów z Wiednia, Sztokholmu czy Moskwy. Natomiast do zestawu imponującej rozmiarami literatury przedmiotu nie można mieć zastrzeżeń.

Rozdział pierwszy poświęcono omówieniu literatury przedmiotu dotyczącej stosunków Rzeczypospolitej z Habsburgami, Szwecją i Moskwą (nazywaną zresztą w pracy konsekwentnie Rosją). Zdumienie budzi pominięcie ważnego sąsiada państwa polsko-litewskiego, jakim była Turcja. Autor omawia literaturę przeważnie w trybie narracji, nieczęsto daje wyraz własnym przekonaniom i rzadko polemizuje. Przeważnie stosuje klucz chronologiczny, ale w wypadku omawiania stosunków polsko-szwedzkich przedstawia szwedzką historiografię do II wojny światowej, potem polską do współczesności, następnie szwedzką po II wojnie światowej.

Trzy kolejne rozdziały to analiza postawy Zygmunta III wobec Habsburgów, Szwecji i Moskwy. W pierwszym z nich Autor ukazuje rolę Habsburgów

${ }^{1}$ Die Hauptinstruktionen Clemens' VIII für die Nuntien und Legaten an den europäischen Fürstenhöfen 1592-1605, wyd. K. Jaitner, t. 1-2, Tübingen 1984. 
w polityce królewskiej w latach 1587-1592, a przecież pozostałe rozdziały doprowadzone są do roku 1618. Skąd ta zaskakująca chronologia w wypadku Habsburgów, tego P. Szpaczyński nie tłumaczy. A przecież cesarz i jego krewni odgrywali ważną rolę w planach polskiego monarchy i po 1592 r. Sądzimy, że twierdzenia tego nie należy specjalnie uzasadniać. Wystarczy wspomnieć chociażby rywalizację polsko-habsburską w latach 1595-1600 w Mołdawii czy zawarcie paktu familijnego między Wazami i Habsburgami w 1613 r. W omawianym rozdziale przedstawiono także obszernie relacje polsko-szwedzkie w kontekście stosunków z Habsburgami i Moskwą. Ponieważ do problematyki habsburskiej jeszcze powrócimy, omówimy jedynie kwestie szwedzkie i moskiewskie. Są one zresztą osią wywodu Autora o mocarstwowych dążeniach Zygmunta III.

Zgłoszenie kandydatury królewicza Zygmunta do tronu polskiego to według P. Szpaczyńskiego rezultat koncepcji połączenia unią personalną Polski i Szwecji, przez co stworzono by podstawy do dalszej ekspansji obu królestw, przede wszystkim w kierunku Moskwy. Twórca tej koncepcji, Jan III, zmienił jednak poglądy po 1585 r. i zaczął forsować ścisłe związki swego królestwa z Danią. W pierwszej fazie trzeciego interregnum szwedzki monarcha był wręcz niechętny wysyłaniu syna do Polski (s. 63-64). Można się zgodzić z wywodem Autora, że Jan III nie wierzył w wybór przez Polaków cara Fiodora, gdyby Zygmunt nie kandydował (s. 64), jednak nie przytoczono argumentów uzasadniających zmianę decyzji króla szwedzkiego. Owszem, fakt wyboru Maksymiliana na polski tron mógłby być niewygodny dla Szwecji, jak sugeruje P. Szpaczyński (s. 68), jednak czy w Szwecji rzeczywiście wiedziano, jakie są szanse poszczególnych kandydatów? Może raczej wrócono do starej koncepcji, zgodnie z którą wychowywano królewicza Zygmunta do panowania w Polsce, a opór Jana III był tylko pozorny w celu wynegocjowania dla syna lepszych paktów konwentów.

Teza Autora, dla którego unia polsko-szwedzka była w planach Jana III i jego syna co najmniej zabezpieczeniem obu królestw przed ekspansją moskiewską, jest do zaakceptowania. Na niej jednak zbudowano hipotezę o mocarstwowych dążeniach Zygmunta III. Opis wysiłków dyplomacji carskiej i dyplomacji habsburskiej, które dążyły do osłabienia polskiego monarchy, a nawet w wypadku arcyksięcia Maksymiliana oraz cara Fiodora do jego detronizacji, wskazuje raczej na kroki młodego Wazy zmierzające do neutralizacji tych dążeń niż na próbę realizacji dążeń mocarstwowych.

Rozdział trzeci poświęcono staraniom Zygmunta III o utrzymanie dziedzictwa szwedzkiego w latach 1592-1618. Autor przedstawia aktywność polityczną księcia Karola Sudermańskiego podważającego systematycznie pozycję króla w jego ojczyźnie. Układ pokojowy zawarty w Tawzinie w 1595 r. między Szwecją a Moskwą, korzystny dla tej ostatniej, słusznie ocenia P. Szpaczyński jako niwelujący sens unii polsko-szwedzkiej (s. 165). Inicjatywa pokoju wyszła ze strony księcia Karola, dziwne więc, że Autor tylko podejrzewa, iż król nie miał na jego warunki większego wpływu, a przecież powinien mieć co do tego pewność. Fakt ten osłabił pozycję monarchy i nic dziwnego, że nielegalnie zwołany przez księcia Karola Riksdag uchwalił wypędzenie katolików i konieczność aprobaty 
decyzji królewskich przez Radę Regencyjną oraz Karola Sudermańskiego. Kolejnym posunięciem stryja królewskiego było rozpędzenie Rady, a gdy polski sejm w 1597 r. nie udzielił monarsze realnego poparcia w Szwecji, położenie króla stało się rozpaczliwe. Można się zgodzić z tezą Autora, że elektorzy brandenburscy nie kwapili się z energicznym poparciem Zygmunta III w konfrontacji z księciem Karolem, gdyż władza Zygmunta III w obu królestwach sprzyjała inkorporacji Prus, a nie przekazania ich w lenno Brandenburgii (s. 185).

W zupełności trzeba przyznać rację Autorowi, gdy stwierdza, że dominujące w historiografii przeświadczenie „iż Zygmunt III, dokonując inkorporacji Estonii, przekształcił konflikt o tron szwedzki w wojnę między dwoma państwami, wydaje się nieporozumieniem" (s. 188). Podobnie sądzi Walter Leitsch, uważający, że do agresji szwedzkiej po detronizacji Zygmunta III i tak by doszło ${ }^{2}$. Należy się też w pełni zgodzić z tezą, że agresję szwedzką w Inflantach przyspieszyły wieści o rozejściu się sejmu 1600 r. bez uchwał (s. 189) oraz z opinią, że podjęta w drugiej połowie tego roku wyprawa Jana Zamoyskiego do Mołdawii i Wołoszczyzny pomogła Szwedom w opanowaniu Inflant (s. 192), ale należałoby też pamiętać, że wzmocnienie pozycji księcia Michała Walecznego w księstwach naddunajskich odpowiadało interesom Habsburgów, a nie Zygmunta III.

Autor opisuje przebieg kampanii wojennej polsko-szwedzkiej lat 1600-1605. Następnie przedstawia wpływ rokoszu na stosunki ze Szwecją. Czy rokosz przekreślił nadzieję króla na odzyskanie tronu szwedzkiego, jak chce Autor (s. 232), czy tylko utrudnił położenie Rzeczypospolitej w Inflantach? Sam zresztą Autor kilkakrotnie, m.in. na s. 236, stwierdza, że Zygmunt III prowadził w Szwecji agitację na rzecz pozbawienia tronu Gustawa Adolfa, a więc nadzieję miał w dalszym ciągu.

W ostatniej części rozdziału przedstawiono relacje Rzeczypospolitej ze Szwecją w latach 1606-1618. Większość wniosków nie budzi zastrzeżeń. Można się zgodzić z tezą, że wkroczenie króla do Rosji doprowadziło Szwedów „do ograniczenia aktywności militarnej w Inflantach" i skoncentrowało ich uwage na Moskwie (s. 233-234). Także zgoda, że król mógł liczyć, iż w razie powodzenia w Moskwie „problem agresji szwedzkiej w Inflantach przestanie istnieć” (s. 234). Z pewnością ma też rację Autor, pisząc, że pokój zawarty między Szwecją a Moskwą w 1617 w Stołbowie pogorszył położenie Rzeczypospolitej w konfrontacji z Moskwą (s. 241). Równie słusznie zauważono korelację między rozpoczęciem wyprawy królewicza Władysława na Moskwę latem 1617 r. z ofensywą szwedzką w Inflantach.

Ostatni z rozdziałów poświęcono imperialnym dążeniom Zygmunta III dotyczącym Moskwy w latach 1592-1618. W sposób interesujący przedstawiono relacje dyplomatyczne między Moskwą a Rudolfem II. Każda ze stron miała inne interesy. $O$ ile cesarz usiłował wciągnąć cara do ligi antytureckiej, to Fiodor proponował przymierze antypolskie i antyszwedzkie. Polityka nowego cara Borysa

${ }^{2}$ W. Leitsch, Sigismund III. von Polen und Jan Zamoyski. Die Rolle Estlands in der Rivalität zwischen König und Hetman, Wien 2006, s. 238; idem, Das Leben am Hof König Sigismund III. von Polen, Wien 2009, t. 2, s. 719-720. 
Godunowa wobec detronizacji Zygmunta III zamieniła wektor antyszwedzki na starania o sojusz antypolski z północnym królestwem. W dalszym jednak ciągu Moskwa próbowała, bez większego powodzenia, wciągnąć Rudolfa II do swych antypolskich planów. Opisując wielkie poselstwo Lwa Sapiehy do Moskwy w 1600 r. i jego fiasko, Autor stwierdza, że Moskwa nie chciała nawet przedłużyć rozejmu i czekała na wieści o sukcesach Michała Walecznego w walkach z Zamoyskim. Zmieniła postawę na wieść o klęsce Michała (s. 266-267). Tym samym P. Szpaczyński przyznaje rację kanclerzowi, że walcząc w księstwach naddunajskich, działał jednak w imię racji stanu. Zapomniał chyba o tym, iż wcześniej obarczał kanclerza winą za sukcesy Szwedów w Inflantach w 1600 r. (s. 192).

W kolejnej części rozdziału opisano przebieg dymitriad w latach 1604-1606. Wedle Autora król, popierając nieoficjalnie sprawę Dymitra, liczył na życzliwość wykreowanego przez Polaków cara i pomoc w walce z księciem Karolem (s. 274), a jego koronacja wzmocniła pozycję króla na arenie międzynarodowej (s. 279-280). Czy bojarzy zawiązali spisek, jak sugeruje Autor, aby uniemożliwić carowi Dymitrowi wojnę z Turcją w obawie, że ewentualny sukces wzmocni jego pozycję? Przecież sam stwierdza, iż poselstwo moskiewskie w Rzeczypospolitej już na początku stycznia 1606 r. sondowało stanowisko polskie na wypadek obalenia cara (s. 282). Tak więc spisek zawiązywany był niemalże od początku jego panowania. Można się natomiast zgodzić, że wieści o zerwanym sejmie 1606 r. i o działaniach opozycji, jakie wraz z orszakiem Maryny przyszły do Moskwy, mogły przyspieszyć realizację zamierzeń bojarów (s. 285).

Sojusz moskiewsko-szwedzki z Wyborga (28 II 1609) był skierowany przeciw Rzeczypospolitej i oznaczał zerwanie rozejmu polsko-moskiewskiego z $1608 \mathrm{r}$. (s. 291). Jak jednak czytamy, „Genezy wojny państwa polsko-litewskiego z Rosją w latach 1609-1618 należy upatrywać w mocarstwowych dążeniach Zygmunta III, który od początku swego panowania w Rzeczypospolitej dążył do walnej rozprawy z Rosją" (s. 292).

Ponadto stwierdzono, że kwestią sporną jest, do czego dążył monarcha, rozpoczynając wojnę z Moskwą w 1609 r. (s. 293). Nie jest to naszym zdaniem słuszna teza. Warto przy tym zauważyć, że Zygmunt III nie odstąpił od oblężenia Smoleńska, i zapewne taki był plan pierwotny albo plan minimum, jak chce Henryk Wisner ${ }^{3}$.

Czy ostateczną decyzję o wojnie z Moskwą podjął król, jak chce Autor, dopiero w marcu 1609 r., po podpisaniu układu szwedzko-moskiewskiego w Wyborgu? (s. 295). Wydaje się, że decyzja nastąpiła wcześniej, skoro w instrukcjach królewskich z listopada 1608 r. na sejmiki przedsejmowe król proponował wojnę z Moskwą i niektóre sejmiki, jak proszowicki, ustosunkowały się do tej propozycji pozytywnie ${ }^{4}$. Można w związku z tym zgodzić się ze stwierdzeniem Autora

${ }^{3}$ H. Wisner, Zygmunt III Waza, wyd. 2, Wrocław 2006, s. 136.

${ }^{4}$ Mikołaj Zebrzydowski, wojewoda krakowski, w liście na sejmik przedsejmowy proszowicki, pisanym z Zamościa (5 XII 1608), stwierdził, że jest dobra okazja moskiewska. Sam sejmik przedsejmowy w Proszowicach (13 XII 1608) postulował: „Akciej 
(za Adamem Darowskim), że Zygmunt III niezależnie od układu z Wyborga zdecydowałby się na wojnę.

P. Szpaczyński myli się jednak, twierdząc, że sejmiki nie poparły wojny z Moskwą, a postawę sejmiku deputackiego z Wiszni popierającego wyprawę królewską uważa za wyjątek (s. 297). Owszem, sejmiki deputackie w 1609 r. uchwaliły podatki na wojnę ${ }^{5}$.

W kolejnej części rozdziału omówiono okoliczności elekcji królewicza Władysława na tron carski. Można się zgodzić z Autorem, że król chciał najpierw zdobyć Smoleńsk, oficjalny cel wojny, a kwestię wyboru Władysława pozostawiał do zatwierdzenia sejmowi. Liczył się bowiem z jego negatywną opinią w sprawie traktatu zawartego przez Stanisława Żółkiewskiego z bojarami (s. 310-311). P. Szpaczyński ma też rację, twierdząc, że monarcha obawiał się, iż Rosjanie zamordują królewicza, zwłaszcza że grupa bojarów popierająca Władysława była w mniejszości (s. 311). Autor stawia również pytanie, czy król myślał o regencji w Moskwie na czas małoletniości królewicza, czy też o władzy dla siebie (s. 312). Przychylamy się do opinii, że raczej miał na myśli regencję. Kolejny problem wywołany przez P. Szpaczyńskiego to kwestia, czy powrót króla do Polski po zdobyciu Smoleńska, zamiast wyruszenia na Moskwę, był błędem. Tak sądzi Wojciech Polak ${ }^{6}$. Autor króla usprawiedliwia i chyba ma rację (s. 314). Tylko sejm mógł zapewnić środki na kontynuację wojny.

Ostatnia część rozdziału ma dziwny tytuł: „Pośrednictwo habsburskie w wojnie Rzeczypospolitej z Rosją". A przecież rola mediacji cesarskiej, nieskutecznej zresztą, była marginesowa i sam Autor poświęcił jej niewiele uwagi. Omówił przede wszystkim obydwa sejmy z 1613 r., sejmy 1615 i 1616 r., a także działania militarne prowadzone przez Rzeczpospolitą.

Problem relacji Zygmunta III z Habsburgami oraz z opozycją wewnętrzną w latach 1587-1592 to najbardziej interesujące wątki monografii, zawierające szereg śmiałych hipotez i tym samym skłaniające do podjęcia dyskusji. Autor, opierając się bardziej na reinterpretacji literatury przedmiotu, w tym - co należy podkreślić - szwedzkiej, niż na badaniach własnych, przedstawia interesującą tezę, że Zygmunt III nie planował nigdy rezygnacji z polskiego tronu. Uważa, iż powszechnie przyjęta teza o tym, że monarcha przynajmniej rozważał taką możliwość, jest nieporozumieniem. Oczywiście najsłabsze w tym wszystkim twierdzenie o potajemnej cesji tronu na rzecz arcyksięcia Ernesta jest łatwe do obalenia, choćby z tego powodu, że tron polsko-litewski nie był dziedziczny i żaden

moskiewskiej, aby nie opuszczać życząc", Akta sejmikowe województwa krakowskiego, t. 1, wyd. S. Kutrzeba, Kraków 1932, s. 329, 337.

${ }^{5}$ Uczynił tak nawet sejmik średzki, który podczas rokoszu należał do wyjątkowo opozycyjnych - pozwolił, „czyniąc zadość żądaniu K.J.M, na pobór łanowy i czopowe oraz „cło czwartego grosza” na rok - Laudum sejmiku deputackiego średzkiego, Środa, 14 IX 1609, Akta sejmikowe województwa poznańskiego i kaliskiego, (dalej Akta średzkie), t. 1, cz. 1, wyd. W. Dworzaczek, Poznań 1957, s. 395.

${ }^{6}$ W. Polak, O Kreml i Smoleńszczyznę. Polityka Rzeczypospolitej wobec Moskwy 1607-1612, Toruń 1995, s. 268. 
władca Rzeczypospolitej nie mógł go nikomu scedować. Sprawa rzekomej cesji czynionej przez króla bez zgody Rzeczypospolitej to ewidentnie demagogiczny zarzut wobec króla stawiany tak przez Zamoyskiego, jak i maksymilianistów.

Autor stawia bardzo śmiałą hipotezę, że sprawa cesji to w gruncie rzeczy intryga dyplomacji szwedzkiej, prowadzona jednak za wiedzą i aprobatą Zygmunta III. Miała ona na celu neutralizowanie wrogich działań dyplomacji cesarskiej, a także prywatnej dyplomacji arcyksięcia Maksymiliana, przede wszystkim w Moskwie, ale i pośrednio w Szwecji (sprawa Gustawa Ericssona, stryjecznego brata polskiego monarchy). Wkrótce po odwiedzinach króla u arcyksięcia Maksymiliana w Krasnymstawie (18 IV 1589) „Szwedzi, którzy przybyli z Zygmuntem III do Polski, podjęli w jego imieniu tajne rokowania z Habsburgami w sprawie cesji tronu Rzeczypospolitej na arcyksięcia Ernesta. Dnia 27 maja 1589 r. hrabia Gustaw Persson Brahe przygotował w tej sprawie list królewski, który Lambert Wrader zawiózł do Grazu, na dwór arcyksięcia Styrii, Karyntii, Krainy i Gorycji Karola II Habsburga" (s. 103). Z przytoczonego cytatu wynika jednak przynajmniej osobista odpowiedzialność Zygmunta III za podjęcie niebezpiecznej gry dyplomatycznej, która nieomal doprowadziła go do utraty tronu polskiego. P. Szpaczyński łączy chronologicznie wizytę monarchy w Krasnymstawie z początkiem kwestii cesji, ale nie wskazuje na związek między nimi. Może jednak kluczowa była rozmowa króla z arcyksięciem i Zygmunt III mógł się przekonać, że kontrkandydat łatwo z pretensji do tronu nie zrezygnuje. Tylko tym można by tłumaczyć podjęcie intrygi dyplomatycznej tak szybko po pobycie w Krasnymstawie.

Autor przytacza szereg argumentów na poparcie hipotezy, że król nie zamierzał nigdy porzucić tronu. Z częścią z nich można się zgodzić. Tak oto twierdzenie, że Zygmunt III czuł się nie tylko potomkiem Jagiellonów, ale i ich spadkobiercą, niewątpliwie uprawomocnia przekonanie, że mógł się poczuwać do odpowiedzialności za Polskę i Litwę i że nie były one dla niego obcymi terytoriami (s. 109). Kolejny argument nie jest jednak tak jednoznaczny. Otóż P. Szpaczyński uważa, że niechęć, a nawet wrogość kanclerza również nie mogły skłaniać króla do rezygnacji z tronu polskiego, ponieważ przenosząc się na stałe do Szwecji i nie zmieniając wyznania, miałby te same, jeśli nie większe problemy ze stryjem Karolem, fanatycznym luteraninem, wykorzystującym religię do walki z bratankiem (s. 111). Warto jednak zauważyć, że miałby wówczas szansę na pilnowanie własnych spraw osobiście. Poza tym nie wiemy, co rzeczywiście myślał młody monarcha w maju 1589 r., gdy wdał się w intrygę dyplomatyczną z Habsburgami. Autor słusznie powątpiewa w wiarygodność zapisu u Reinholda Heidensteina, że król wkrótce po koronacji miał powiedzieć, iż odda tron wraz z ręką swej siostry arcyksięciu Ernestowi (s. 112).

P. Szpaczyński podkreśla, że władca nie zamierzał rezygnować ze ślubu z luterańską księżniczką Holsztynu i że małżeństwo z jedną z Habsburżanek poparli na sejmie pacyfikacyjnym niemal wszyscy senatorowie z Zamoyskim na czele (s. 113). Stawia też słuszną tezę, że małżeństwo króla z arcyksiężniczką Anną wykluczało możliwość cesji tronu, gdyż osłabiało jego pozycję w Szwecji; 
co innego poprzednie plany mariażu z księżniczką Holsztynu - te mogły ułatwiać rezygnację z Polski, gdyż wzmacniały pozycję Zygmunta wobec luterańskich poddanych w Szwecji (s. 127). Jednak, o czym Autor zdaje się zapominać, król aż do zjazdu w Rewlu (wrzesień 1589) obstawał przy pierwotnych planach matrymonialnych. W związku z tym w maju 1589 r. mógł uważać małżeństwo $\mathrm{z}$ luteranką za korzystne. A to $\mathrm{z}$ kolei nie wyklucza świadomego $\mathrm{w}$ tym czasie zamiaru abdykacji.

Szwedzi skupieni wokół Zygmunta III kontynuowali intrygę dyplomatyczną z Habsburgami w 1590 r., a sam monarcha nie zamierzał niczego dementować. Przed pierwszym sejmem 1590 r. i w jego trakcie król zwierzył się niektórym senatorom, biskupowi kujawskiemu Hieronimowi Rozdrażewskiemu, wojewodzie krakowskiemu Mikołajowi Firlejowi i marszałkowi wielkiemu koronnemu Andrzejowi Opalińskiemu, że „myśli o wyjeździe na jakiś czas do Szwecji” (s. 130). Jak stwierdza Autor, wielu z nich interpretowało to jako chęć abdykacji, np. A. Opaliński, który prosił króla o zaniechanie tego pomysłu. Nic w tym dziwnego, skoro w tym czasie nawet w Stambule mówiono o abdykacji polskiego monarchy. Sam zresztą Zygmunt III poczuł się zmuszony do złożenia 12 kwietnia 1590 r. deklaracji, że nie zamierza abdykować, a rokowania z Habsburgami dotyczą spraw matrymonialnych.

Warto przypomnieć, że dyplomacja habsburska cały czas usiłowała nakłonić króla, aby zrzekł się tronu na rzecz Maksymiliana. Czyniono tak jeszcze w pierwszej połowie 1590 r. Dopiero w maju wysłannik arcyksięcia Jonas von Heissberg, wobec stanowczej niechęci monarchy do Maksymiliana, oświadczył, że ofertę mógłby przyjąć Ernest. Ostatecznie tekst traktatu wynegocjowany przez króla i podpisany przez Ernesta otrzymał monarcha pod koniec grudnia $1590 \mathrm{r}$. za pośrednictwem posłów cesarskich, biskupa wrocławskiego Jerina i barona Richarda Streina. Jak podkreśla Autor, traktatu nigdy nie podpisał Zygmunt III. „Akt miał wejść w życie pod warunkiem zgody sejmu Rzeczypospolitej na przekazanie przez króla po abdykacji tronu Ernestowi Habsburgowi”. Sejm miał też zgodzić się na sojusz ze Szwecją i na rezygnację z Estonii. Arcyksiążę miał zaś spłacić stare długi Zygmunta Augusta, szwedzkie wydatki na elekcję w 1587 r., załatwić zwrot sum neapolitańskich oraz zwrot księstw Bari i Rossano, a także jako król polski zrzec się spadku po królowej Annie Jagiellonce (po aprobacie tego przez sejm) (s. 133). Zygmunt III udzielił posłom odpowiedzi (21 I 1591), twierdząc, że nie zgadza się na przekazanie korony Maksymilianowi i ma nadzieję, że ten nie będzie przeszkadzał Ernestowi. Niczego też nie podpisał. Analiza treści traktatu świadczy jednoznacznie, że przynajmniej we wrześniu 1590 r., a więc w czasie, gdy propozycje królewskie skrystalizowały się w postaci ostatecznego projektu, monarcha nie zamierzał rezygnować z polskiego tronu. Warunki bowiem, jakie postawił, były nie do zaakceptowania przez polski parlament. Trudno sobie wyobrazić, aby sejm nie tylko zaaprobował abdykacje Zygmunta III, ale jeszcze wyraził zgodę na, w praktyce, elekcję vivente rege! Również warunki postawione Ernestowi były niewykonalne. Czy mógł bowiem sprawić, aby zwrócono nie tylko sumy neapolitańskie, ale również księstwa Bari 
i Rossano? Do tego nie wystarczała zgoda cesarza, konieczna była przede wszystkim aprobata Filipa II. Obie więc strony grały „bardzo wysoko”. Jak się wydaje, król wiedział, że pula nagród jest pusta. Czy był tego świadomy także Ernest?

Autor twierdzi, że nie są właściwe interpretacje takich historyków jak Wacław Sobieski, Kazimierz Lepszy czy H. Wisner, że w 1591 r. król zaczął się wahać w sprawie swojej abdykacji. Uzasadnia to tym, że Zygmunt III był władcą konsekwentnym i znanym z uporu, więc bezpodstawne jest, według niego, łączenie wahania króla z kruszeniem pozycji politycznej kanclerza. Z tym ostatnim można się zgodzić, gdyż stronnictwo Zamoyskiego było jeszcze dość silne. Jak stwierdziliśmy powyżej, zasadniczym argumentem na rzecz tego, że monarcha, co najmniej od wczesnej jesieni 1590 r., nie myślał o abdykacji, jest analiza treści ostatecznego traktatu między nim a arcyksięciem Ernestem.

Jeszcze jedna kwestia związana z planami abdykacji budzi wątpliwości interpretacyjne. Jak stwierdza Autor: „Ujawnienie treści tajnych rokowań z woli arcyksięcia Maksymiliana, po ponad półtora roku od podpisania przez arcyksięcia Ernesta wypracowanego w ostatecznej formie układu, bez żadnego odzewu ze strony Zygmunta III, wydaje się być osobliwą formą zemsty domu habsburskiego, nie zaś zdradą dynastii przez arcyksięcia Maksymiliana" (s. 144-145). Trudno się z tym wywodem zgodzić. Gdyby tak było, to oznaczałoby, że Habsburgowie chcą narażać swego powinowatego (wówczas narzeczonego arcyksiężniczki Anny) na detronizację w Polsce. Trzeba zatem przyznać rację raczej W. Leitschowi, że była to osobista zemsta niezbyt roztropnego Maksymiliana, który ponadto liczył na objęcie tronu w Krakowie po detronizacji Zygmunta III ${ }^{7}$. o tym, że nie chodziło w tym wypadku o zemstę Habsburgów, przekonuje dodatkowo przytoczony przez Autora fakt, iż na prośbę króla cesarz wstrzymał wysłanie kolejnego agenta Maksymiliana do Polski (przytacza to za Leitschem). Autor słusznie stwierdza, że Maksymilian i jego stronnicy liczyli, iż po detronizacji Zygmunta III arcyksiążę obejmie tron polski (s. 145). Niewątpliwie zaś utwierdzał ich w tym Zamoyski - stąd sojusz kanclerza z maksymilianistami, o czym Autor jednak nie pisze.

Podsumowując rozważania o problemie ewentualnej cesji tronu, należy stwierdzić, że P. Szpaczyński poruszył ważną kwestię i postawił śmiałą hipotezę. Niewątpliwie jego wywody podważyły w pewnym stopniu dotychczasowe stanowisko historiografii, ale go nie obaliły, ponieważ hipoteza „gry dyplomatycznej”, aczkolwiek atrakcyjna, jest nie do udowodnienia, gdyż opiera się na hipotetycznym założeniu, że dla Zygmunta III wszystko od początku było świadomie podjętą grą pozorów. Jednak co monarcha myślał naprawdę w maju 1589 r., nie wiemy i zapewne nigdy się nie dowiemy.

Materiał przedstawiony przez Autora pozwala z całą pewnością stwierdzić, że przynajmniej od września 1590 r. król nie traktował serio zobowiązań w sprawie cesji. Można jednak założyć, że stało się to jeszcze wcześniej. Chodzi nam tutaj o pierwotne zobowiązania matrymonialne Zygmunta III, które ułatwiały

\footnotetext{
7 W. Leitsch, Sigismund III. von Polen, t. 1, s. 109-110.
} 
podjęcie decyzji o cesji. Jednak już w Rewlu, o czym zresztą P. Szpaczyński pisze, Jan III zaakceptował pomysł mariażu habsburskiego swego syna (wrzesień 1589). Realizacja tego pomysłu podważała z kolei sens abdykacji z tronu polskiego, gdyż osłabiała pozycję Zygmunta III w Szwecji. Może więc od tego momentu rokowania prowadzone z Habsburgami był jedynie zasłoną dymną dla celu realnego, to znaczy zgody cesarza na małżeństwo młodego Wazy $\mathrm{z}$ arcyksiężniczką austriacką.

P. Szpaczyński słusznie stwierdza, że pomoc teściowej arcyksiężnej Marii Styryjskiej ułatwiła królowi stosunkowo gładkie wyplątanie się z afery abdykacyjnej. Dodać można, że jej pośrednictwo przydało się jeszcze kilkakrotnie Zygmuntowi III, przede wszystkim w rokowaniach o ligę antyturecką i w łagodzeniu antypolskich pomysłów dyplomacji cesarskiej. Teściowa bowiem bardzo lojalnie pilnowała interesów ulubionego zięcia.

Ostatnia kwestia, której chcielibyśmy się bliżej przyjrzeć, to relacje kanclerza Jana Zamoyskiego z królem. Autor słusznie uważa, że podczas trzeciego bezkrólewia hetman wielki koronny myślał o koronie dla siebie. Dla poparcia tej tezy przytacza jedynie opinię toskańskiego dyplomaty (s. 56). Choć takich argumentów można znaleźć o wiele więcej, niektóre z nich przytoczone są zresztą w książce, tyle tylko, że w innym miejscu. Zacznijmy od przypomnienia słusznej uwagi P. Szpaczyńskiego, że kanclerz nie stawiał otwarcie swej kandydatury na sejmie elekcyjnym, obawiając się porażki. Nie zauważył przy tym, że Zamoyski sondował własną popularność na elekcji. Otóż jego kandydaturę jako Piasta, zgłosił w dniu 15 sierpnia w kole antykonwokacyjnym Prokop Pieniążek, starosta wendeński i niewątpliwy zamoyszczyk. Propozycja ta została jednak zignorowana przez zgromadzoną szlachtę ${ }^{8}$. Dzień wcześniej, podczas wotowania nad kandydatami w kole antykonwokacyjnym, kanclerz, w przeciwieństwie do pozostałych senatorów, zachwalając Piasta, ani słowem nie wspomniał o królewiczu szwedzkim'. Więcej, oświadczył, że jeśli wybiorą Piasta, da elektowi ze swego majątku 100 tys. zł.

Zamoyski przeszedł na stronę Zygmunta dopiero wówczas, gdy w kole antykonwokacyjnym zaczęła przeważać wyraźnie kandydatura szwedzka, utożsamiana przez wielu z piastowską. Charakterystyczne jednak, że kanclerz w dalszym ciągu zachowywał wyraźny dystans do królewicza. Nie był na przykład w kole antykonwokacyjnym w dniu 19 sierpnia 1587 r., gdy prymas nominował na króla Zygmunta Wazę, co zresztą zauważył P. Szpaczyński. Jak pisze autor diariusza sejmu elekcyjnego: „Pan Kanclerz tego dnia przez wszystek dzień nie był i przy nominacji, ale uczyniwszy opatrzność ludźmi, żeby wojska naciągające na Senatory i rycerstwo w Kole będące impetum nie czyniły"10. Interesujące, że w dwa dni później, gdy zebrali się na zamku senatorscy zwolennicy Wazy,

${ }^{8}$ Diariusz elekcji 1587, w: Diariusze sejmowe R. 1587. Sejmy konwokacyjny i elekcyjny, wyd. A. Sokołowski, Kraków 1887, Scriptores Rerum Polonicarum (dalej SRP), t. 11, s. 111.

9 Ibidem, s. 103.

10 Ibidem, s. 130. 
również nie było między nimi kanclerza koronnego ${ }^{11}$. Słuszna jest uwaga Autora, że hetman wielki nie podpisał ani aktu elekcji, ani recesu sejmu elekcyjnego. W Wiślicy 8 października Zamoyski, przemawiając do zebranych zwolenników Wazy, ani słowem nie napomknął o nim, mimo iż wiedział o jego przybyciu do Gdańska. Nie podpisał też uniwersału wiślickiego potwierdzającego wybór królewicza szwedzkiego. Wszystko to potwierdza tezę, że kanclerz nie był w 1587 r. zwolennikiem wyboru na tron polski Jagiellona po kądzieli. Jeśli zaś nie był, w co nikt nie wątpi, adherentem Habsburga, to kogo pragnął widzieć na Wawelu? Sam odżegnywał się od posądzeń, że myśli o sobie. W liście do Mikołaja Krzysztofa Radziwiłła kasztelana trockiego (2 V 1587) oświadczył stanowczo, że nie będzie popierał kardynała Batorego, bo nie ma on żadnych szans i nie myśli także o koronie dla siebie ${ }^{12}$. Wielu historyków, w tym K. Lepszy, W. Leitsch i P. Szpaczyński, podejrzewało hetmana, że myślał o koronie dla siebie, ale jak stwierdził K. Lepszy, kanclerz nie pozostawił żadnych śladów w źródłach na poparcie takiego przypuszczenia ${ }^{13}$.

Czy w związku z tym jesteśmy skazani jedynie na domysły, których nie sposób udowodnić? Wydaje się, że można spróbować połączyć ze sobą poszczególne działania Zamoyskiego, a Autor monografii tego nie czyni, w celu uchwycenia wspólnej dla nich myśli przewodniej. Istnieją poza tym pośrednie przesłanki źródłowe. Wiele mówiąca była reakcja Litwinów na elekcję królewicza Zygmunta. Otóż poselstwo litewskie wysłane 22 sierpnia do senatorów koronnych oświadczyło: „obawiamy się, aby pod osobą Królewica Szwedzkiego nie dano nam jakiego Piasta albo Batorego"14. Ta oczywista aluzja do planów Zamoyskiego jest wyraźnym potwierdzeniem podejrzenia, że kanclerz myślał o koronie dla siebie. P. Szpaczyński, idąc za stwierdzeniem W. Leitscha, słusznie zauważa, że hetman dał punkt o Estonii do paktów konwentów, aby królewicz nie mógł przyjąć korony (s. 76). Znalazł się też w składzie trzyosobowej komisji układającej warunki dla Zygmunta Wazy ze swoimi ludźmi, mianowicie z Marcinem Leśniowolskim, kasztelanem podlaskim, i Wojciechem Baranowskim, podkanclerzym koronnym ${ }^{15}$. Chciał mieć zatem stuprocentową pewność, że będzie mógł przeforsować artykuł o Estonii.

Strategia obliczona na ponowną elekcję po odrzuceniu przez królewicza szwedzkiego paktów konwentów zawiodła całkowicie, gdyż uzyskał on odroczenie decyzji o cesji do czasu objęcia tronu szwedzkiego. Klęska Zamoyskiego była tym dotkliwsza, że nawet jego zaufani, jak Leśniowolski czy Baranowski,

11 Ibidem, s. 140-141.

12 J. Zamoyski do M.K. Radziwiłła kasztelana trockiego, Zamość, 2 V 1587, w: Archiwum Jana Zamoyskiego kanclerza i hetmana wielkiego koronnego, t. 4: 1585-1588, wyd. K. Lepszy, Kraków 1948, s. 115-116.

${ }^{13}$ K. Lepszy, Walka stronnictw w pierwszych latach panowania Zygmunta III, Kraków 1929, s. 45.

14 SRP, t. 11, s. 155.

${ }^{15}$ Ibidem, s. 155. 
okazali się szczerymi zwolennikami panowania Jagiellona po kądzieli. Zawiódł również atak kanclerza na elekta na sejmie koronacyjnym - kiedy postawił $\mathrm{w}$ formie ultymatywnej postulat natychmiastowej cesji Estonii, żądania tego nikt nie poparł (s. 85, 86-87). Niemniej, jak pisał W. Leitsch, sprawa Estonii była jeszcze dla Zamoyskiego wielokrotnie użyteczna.

Jak się wydaje, P. Szpaczyński, po opisaniu zjazdu w Rewlu, porzuca myśl, że hetman w dalszym ciągu myślał o koronie dla siebie. Świadczyć o tym może powoływanie się przez niego na opinię Jana Dzięgielewskiego, iż kanclerz chciał narzucić Zygmuntowi III swą autorytarną radę i uczynić z niego malowanego króla (s. 90).

Autor monografii trafnie zauważa, że Zamoyski konsekwentnie podważał pozycję monarchy, czynił tak zarówno przed zjazdem w Rewlu, jak i po nim. Jego zdaniem kanclerz nie wierzył wówczas w możliwość abdykacji króla (s. 121). Kolejną okazję dla hetmana w realizacji planu objęcia panowania w Rzeczypospolitej dostarczył niewątpliwie sejm wiosenny 1590 r. Jak już pisaliśmy powyżej, pogłoski o „praktykach rakuskich” były wówczas tak poważne, że zmusiło to króla do oficjalnego zaprzeczenia, iż zamierzał opuścić tron, i oświadczenia, że z Habsburgami pertraktował jedynie w sprawach matrymonialnych. P. Szpaczyński do obrad tego sejmu nie przywiązuje większego znaczenia. Zauważa wszakże, że wykluczono wówczas od tronu arcyksięcia Maksymiliana, a kanclerz chciał ponadto ekskluzji wszystkich Habsburgów. Oczywiście zwraca też uwagę na wyolbrzymienie niebezpieczeństwa tureckiego, powiększenie prerogatyw hetmańskich na wypadek wojny z Turcją i uchwalenie pogłównego. Nie łączy tego wszakże w całość, nawet przy okazji wspomnienia, że Zamoyski poczuł się zmuszony do zdementowania pogłoski o swym zamiarze ubiegania się o polski tron $^{16}$. A przecież to wszystko układa się w spójną i logiczną całość. Co wiedział kanclerz przed sejmem wiosennym 1590 r. o planach Zygmunta III? Zdaniem K. Lepszego Zamoyski zdobył „skądś” informacje o oświadczeniu arcyksięcia Maksymiliana, że w sprawie polskiej będzie milczał przez rok, a następnie poinformuje wszystkich i że już o tym powiadomił króla Jana III Wazę. W swym wotum podniósł kwestię wielkiego zagrożenia ze strony Turcji oraz praktyk arcyksięcia Maksymiliana dotyczących tronu polskiego. Dodał przy tym, że Habsburg napisał, że czyni wszystko „sciente et suffragante Sveco" ${ }^{17}$. Oczywiście dodał, że w te rewelacje nie wierzy. K. Lepszy słusznie zauważa, iż była to świadoma taktyka kanclerza zmierzająca do wykluczenia od tronu wszystkich Habsburgów. Sukces Zamoyskiego przeraził zwolenników Maksymiliana. Odczuli go jako zagrożenie dla ich kandydata. Potwierdził to pośrednio na zjeździe w Lublinie w 1592 r. Mikołaj Kazimierski, mówiąc, że bał się, aby król nie wyjechał wtedy z kraju. Przestraszony, hamował opozycję sejmową, „abyśmy tym rychlej Pana nie ustraszeli; był żołnierz in armis z J.M.P. Hetmanem, któregośmy się bali, i nie chciałem na to zezwolić, ażby żołnierza uprzątnowszy,

${ }^{16}$ K. Lepszy, op. cit., s. 131-132, 136.

17 Ibidem, s. 135-136. 
a J.M. Pan Hetman broń swą zawiesił"18. Czy Zamoyski liczył się wówczas z bezkrólewiem, jak sądzi K. Lepszy, czy nie wierzył w zamiary abdykacyjne króla, jak sądzi P. Szpaczyński? Jeśli przyznamy rację temu ostatniemu, to mamy i tak do czynienia z sytuacją, w której hetman był na taką okoliczność bardzo dobrze przygotowany.

Wkrótce jednak okoliczności sprzyjające kanclerzowi uległy radykalnej zmianie. Zadecydował o tym zjazd kolski (10 VIII 1590), zwołany nie, jak twierdzi Autor monografii, przez prymasa Stanisława Karnkowskiego (s. 136), ale na mocy decyzji podjętej 3 lipca przez sejmik posejmowy w Środzie. Stało się to wprawdzie z inicjatywy prymasa i przywódcy wielkopolskich luteran wojewody poznańskiego Stanisława Górki, ale żaden z nich na otwartą konfrontację z królem i kanclerzem sobie nie pozwolił. Szansą dla króla, jak stwierdził P. Szpaczyński, było postawione przez zjazd żądanie rezygnacji z podatku pogłównego, uchwalonego na sejmie, i anulowania nadzwyczajnych pełnomocnictw dla hetmana wielkiego koronnego, któremu zarzucono wyolbrzymienie tureckiego zagrożenia. Jak trafnie zauważono (s. 137), król nie mógł zaaprobować uchwał kolskich, ponieważ zwołanie zjazdu łamało monopol monarchy w tym zakresie, kasacja zaś pogłównego i innych konstytucji sejmowych godziła w uprawnienia sejmu. Był jednak jeszcze jeden bardzo ważny powód, dla którego Zygmunt III musiał być niechętny zjazdowi kolskiemu. Otóż, o czym Autor zapomina, w Kole uchwalono nie tylko artykuły antyhetmańskie, ale również antykrólewskie. Chciano bowiem osłabić prawo nominacyjne monarchy na rzecz senatu oraz prawo do konkluzji wotów senatorskich ${ }^{19}$.

Uchwały sejmu 1590/1591 r. zaaprobowały anulowanie pogłównego i nadzwyczajnych pełnomocnictw dla hetmana. Okazja do sprowokowania przesilenia elekcyjnego minęła. Przez niemal cały rok 1591 Zamoyski zachowuje się poprawnie wobec Zygmunta III. Dopiero w kwietniu 1592 r. kanclerz zjawia się na nielegalnym zjeździe protestantów i maksymilianistów w Lublinie. Zadecydowało o tym kilka czynników. Otóż miał się tam pojawić goniec arcyksięcia Maksymiliana Jan Ducker i hetman wiedział, że przedstawi publicznie interesujące go informacje. Poza tym król sfinalizował już rokowania o rękę arcyksiężniczki Anny, wreszcie Zamoyski porozumiał się z maksymilianistami, których przywódca M. Kazimierski zgodził się na każdego Piasta zaproponowanego przez hetmana. Trudno przypuszczać, że kanclerz nie myślał wówczas o sobie. Autor nie zauważył obecności Duckera w Lublinie, wspomina jedynie, że posądzano wówczas króla o zamiary abdykacji i cesję tronu na rzecz Ernesta, nie wskazuje jednak źródła tych posądzeń (s. 143). Tymczasem Ducker na polecenie swego mocodawcy wyjawił publicznie rokowania Zygmunta III z arcyksięciem Ernestem. W tej sytuacji szlachta zgromadzona w Lublinie zażądała, aby król zwołał sejm jeszcze przed swym ślubem, a sam ślub został odłożony. Zygmunt III nie

18 Diariusz i akta sejmikowe z roku 1591-1592, wyd. E. Barwiński, Kraków 1911, SRP, t. 21, s. 424 .

${ }^{19}$ Akta średzkie, t. 1, cz. 1, s. 99. 
mógł, co oczywiste, wyrazić na to zgody, gdyż skompromitowałby się w oczach Habsburgów i przyznałby rację opozycji. Detronizacja w tej sytuacji byłaby tylko kwestią czasu. Kanclerz niewątpliwie podsycał niezadowolenie szlachty. Świadczy o tym wotum, w którym potwierdził fakty podane na zjeździe, po czym dodał, iż wie więcej, „i na swym placu obiecał to powiedzieć” ${ }^{20}$. List Zamoyskiego do króla (30 V 1592) tylko pozornie ma pojednawczy charakter. Kanclerz stwierdza w nim bez ogródek, że czytał listy o praktykach Maksymiliana i Ernesta. Jego zdaniem doszłoby na zjeździe do jeszcze większego napięcia, gdyby nie zapobiegli temu senatorowie. Dlatego on sam jedzie nie na wesele królewskie, ale na zjazd do Jędrzejowa, „tam gdzie o Rzpltej i o zabieżeniu tem praktykom mówić chcą"21.

Zjazd w Jędrzejowie (1-5 VI 1592), na który ponownie przybył Ducker i którego obecność dopiero teraz Autor zauważył, był niewątpliwie przygotowaniem radykalnej opozycji do kampanii sejmikowej przed sejmem inkwizycyjnym. Instrukcja dana posłom do króla ze zjazdu jędrzejowskiego potwierdza to przypuszczenie w sposób jednoznaczny: „zniosły się poszlakowania tych praktyk, aby o nich na sejmikach wszyscy wiedzieć mogli i tem sposobem tem pilniej jem zabiegali, gdyż na każdy sejmik stawić się nie mogą ci co to pokazowali, a na każdym sejmiku wiedzieć to trzeba"22. P. Szpaczyński nie wspomina, że uczestnicy zjazdu jędrzejowskiego grozili królowi rokoszem w razie odwlekania terminu rozpoczęcia obrad sejmu. Oczywiście pełna zgoda z Autorem, że kanclerz w pierwszej połowie 1592 r. chciał skłócić króla z Habsburgami (s. 144). Zamoyski oczywiście, wbrew temu, co twierdzi K. Lepszy, nie pojechał do Jędrzejowa, aby pacyfikować nastroje, ale aby zaognić sytuację ${ }^{23}$. Pośrednim na to dowodem jest wystąpienie na przedsejmowym sejmiku proszowickim z 8 sierpnia 1592 r. jego bardzo bliskiego współpracownika Mikołaja Zebrzydowskiego, podówczas wojewody lubelskiego. Wojewoda stwierdził w nim, że króla ani w Lublinie, ani w Jędrzejowie o nic nie oskarżano, po czym sam podważył wiarygodność monarchy:

Praktyk też ani z Lublina, ani z Jędrzejowa nie zadawano królowi Jmci, a wdy oba razy sprawować się to raczy, jakoby ci cudzoziemcy, którzy mogli być i samej Rewelskiej kaucyej przyczyną, nie mogli dla questu swego te kondycye imieniem Króla Jmci i nad wiadomość jego podawać, upewniając dla questu swego znowu tegoż Króla JM przywieść i rzeczy nasztychowaćéc.

Gdyby więc ktoś ze szlachty miał wątpliwości co do winy Zygmunta III, to Zebrzydowski je rozprasza. Jego wotum kończy się nawoływaniem, aby jechać na sejm „w jako największej frekwencji osób”.

20 SRP, t. 21, s. 425.

${ }^{21}$ J. Zamoyski do Zygmunta III, Wiślica, 30 V 1592, ibidem, s. 435.

22 Ibidem, s. 84.

${ }^{23}$ K. Lepszy, Rzeczpospolita polska $w$ dobie sejmu inkwizycyjnego, Kraków 1939, s. 345.

${ }^{24}$ Ibidem, s. 166. 
Autor obarcza winą za sejm inkwizycyjny dyplomację habsburską (s. 151152), nie dostrzegając konsekwentnej polityki kanclerza, który nie tylko wykorzystał rewelacje Duckera, ale zawarł również taktyczny sojusz z maksymilianistami. Trudno powiedzieć, czy P. Szpaczyński uważa, że hetman miał zamiar zdetronizować monarchę, przytacza bowiem jedynie opinię nuncjusza Germanica Malaspiny, który tak właśnie stwierdził (s. 145), nie zostało to jednak skomentowane.

Czy zatem Zamoyski zamierzał na sejmie inkwizycyjnym przeprowadzić detronizację króla? Kilkakrotnie jego zachowanie wskazuje na taką możliwość. Po pierwsze, zjawił się na sejmie z wojskiem. Po drugie, spóźniwszy się celowo na początek sejmu, pytał prowokacyjnie Zygmunta III, czy może uczestniczyć w obradach. „P. Ciekliński obmawiał p. Kanclerza, że dziś zjachać nie mógł: pytał możeli przyjachać. KJMć powiedział: Może, dlatego sejm złożony, aby każdy przyjachał"25. Scena z udziałem Cieklińskiego miała zasugerować przynajmniej części senatorów i posłów, że król tak źle traktuje kanclerza, że aż zabrania mu przybycia na sejm. Było to jednocześnie pośrednie wytłumaczenie, dlaczego Zamoyski musiał przyjechać na obrady parlamentu w asyście wojska. Po trzecie wreszcie, hetman forsuje pomysł surowej inkwizycji obejmującej monarchę, dąży więc do skompromitowania go w takim stopniu, aby detronizacja była faktem naturalnym.

P. Szpaczyńskiego nie interesuje, dlaczego Zygmunt III utrzymał się na tronie. Opisuje jedynie wystąpienia senatorów i kolejne deklaracje królewskie (s. 146-147). Konkluduje zaś stwierdzeniem: „Sejm inkwizycyjny, ostatnia wielka próba przejęcia władzy przez kanclerza, która miała się zakończyć sądem nad Zygmuntem III i jego detronizacją, zakończyła się totalnym fiaskiem” (s. 149). Tym bardziej warto zadać pytanie, dlaczego tak starannie przygotowane działania podjęte przez Zamoyskiego w sojuszu z maksymilianistami zakończyły się na niczym. Kluczowe jest naszym zdaniem stanowisko zdecydowanej większości senatorów i posłów, którzy zdając sobie sprawę z powagi sytuacji, nie chcieli doprowadzić do nowej elekcji. Dlatego też nie udało się kanclerzowi i jego stronnikom przeforsować bezpośredniego sądu nad monarchą, a także uniemożliwić zadawanie mu pytań. Gdyby na to przystano, wówczas nawet w wypadku nieudowodnienia królowi winy, byłby on skompromitowany i odarty z resztek autorytetu. Zatem albo by go zdetronizowano, albo musiałby abdykować. W tej sytuacji Zamoyski wyrósłby na zbawcę ojczyzny i jego szanse na tron byłyby niemal pewne. Nie chciano jednak do tego dopuścić. W związku z tym nawet większość izby poselskiej nie chciała uczestniczyć w inkwizycji, pozostawiając ją całkowicie w rękach senatu.

Kanclerz już w trakcie obrad sejmu zrozumiał, że jego szanse na tron są znikome. Zmienił też swoją postawę, jego późniejsze wystąpienia straciły ostrze antykrólewskie. Nastąpił wkrótce blisko dziesięcioletni okres współpracy króla z Zamoyskim. Owocem było zahamowanie ekspansji habsburskiej na Bałkanach i wspólna z monarchą polityka wobec planów ligi antytureckiej.

${ }^{25}$ Ibidem, s. 206. 
P. Szpaczyński dostrzega poszczególne posunięcia hetmana, nie łączy ich jednak w całość. W rezultacie trudno mu interpretować choćby rolę kanclerza w relacjach króla z Habsburgami. Paradoksalnie przy tym, sejm inkwizycyjny ułatwił monarsze wyplątanie się z niebezpiecznej dla niego i państwa gry politycznej, jaką z domem cesarskim prowadził od maja $1589 \mathrm{r}$. W okresie współpracy Zamoyski pomagał Zygmuntowi III w instrumentalnym wykorzystywaniu relacji z Habsburgami w interesie polskiej racji stanu.

W recenzowanej pracy znalazła się pewna liczba błędów. Tytułem przykładu podajmy niektóre z nich. Tak więc Autor stwierdził (s. 65-66), że sejm konwokacyjny 1587 r. „obradował do 9 marca pod przewodnictwem wojewody płockiego Stanisława Uchańskiego". Są tu dwa błędy - Stanisław Uchański był wojewodzicem płockim i nie kierował sejmem, tylko był marszałkiem izby poselskiej. W przypisie 243 (s. 91) Autor się pogubił. Jako przykład zdominowania Wielkopolski przez maksymilianistów w 1587 r. podał uchwałę sejmiku średzkiego z 19 września. Tymczasem laudum to popiera w pełni królewicza Zygmunta, więcej, uchwalono w jego obronie pospolite ruszenie ${ }^{26}$. Przypis ten jest zresztą zbędny, gdyż w tym miejscu Autor omawia sytuację po klęsce arcyksięcia pod Byczyną. Dwie pomyłki dotyczą korzystania z edycji Przeździeckiego Listów Annibale di Capua zamiast z wydania J.W. Wosia. Nie jest więc prawdą, że nuncjusz informował kardynała Montalto o pobycie arcyksięcia Maksymiliana w Krasnymstawie w liście z 10 lutego 1588 r. pisanym z Warszawy, gdyż uczynił to w liście z 28 lutego pisanym z Witowa (s. 95, przyp. 264) ${ }^{27}$. Drugi błąd jest poważniejszy (s. 100, przyp. 297). Otóż datacja listu nuncjusza z 27 marca 1589 r. do kardynała Montalto jest wprawdzie słuszna, ale treść inna. Nuncjusz w tym liście nie pisze bowiem, że król chciał zgody sejmu na „pobór powszechny" i zgody na wypowiedzenie wojny Moskwie, ale donosi o próbach czynionych przez protestantów w sprawie uchwalenia egzekucji do konfederacji warszawskieje.

Autor podaje (s. 187), za Barbarą Janiszewską-Mincer, że na sejmie $1600 \mathrm{r}$. kasztelan liwski Jan Wodyński radził rozpocząć wojnę z Moskwą. Tymczasem Jan Wodyński już dawno nie żył, a kasztelanem liwskim był wówczas Adam Mniszewski, znany regalista, który w 1607 r. awansował na kasztelanię czerską ${ }^{29}$. Trudno się zgodzić, że wśród protestanckich posłów wielkopolskich na sejm 1606 r. wymieniono Macieja Smoguleckiego, starostę bydgoskiego, i Jarosza Rozdrażewskiego (s. 187), owszem, posłowali oni ze Środy, ale byli katolikami. Autor

${ }^{26}$ Laudum - instrukcja sejmiku średzkiego z 19 IX 1587 na zjazd do Wiślicy - Akta średzkie, t. 1, cz. 1, s. 54.

27 Annibale di Capua do kardynała Alessandro Montalto, w: Annibale di Capua. Nunzio apostolico e arcivescovo di Napoli (1544 c.-1595). Materiali per una biografia, wyd. J.W. Woś, Roma 1984, s. 145.

28 Annibale di Capua do kardynała Alessandro Montalto, Warszawa, 27 III 1589, w: Annibale di Capua. Nunzio apostolico, s. 196-199.

${ }^{29}$ Notowany jako kasztelan liwski już 5 IV 1596 (MK 154, k. 67), otrzymał awans na kasztelanię czerską 20 IV 1607 (MK 151, k. 159). 
ewidentnie (s. 218-219, przyp. 436) nie odróżnia dwóch Herburtów i sądzi, że Jan Szczęsny był chorążym lwowskim, choć urząd ten sprawował w tym czasie Jan Herburt (1606) ${ }^{30}$.

Niektóre pomyłki wiążą się z pewną niefrasobliwością Autora. Występuje na przykład dziwna pisownia nazwiska Wilhelma Rožemberka, mianowicie von Rozemberk (s. 98). Nie jest to ani forma czeska, ani niemiecka. Należy wykluczyć również możliwość literówki, gdyż w indeksie jest forma identyczna. Natomiast w przypisie 285 na tejże stronie jest prawidłowa forma niemiecka: Rosenberg (s. 200). Nie jest prawdą, że Szczęsny Kryski, którego zresztą Autor nazywa Feliksem, był w czasie marszałkowania sejmowi 1603 r. referendarzem koronnym. Był wówczas jedynie wojewodzicem mazowieckim, a nominację na referendarza dostał 9 kwietnia $1606 \mathrm{r} .{ }^{31}$ Błąd ten jest tym dziwniejszy, że w przypisie 315 mamy prawidłowe dane Kryskiego.

Dziwnie brzmi zdanie, że król w uniwersale (28 II 1607) potępiającym zjazd w Kole: „Apelował do zebranych, aby w spokoju oczekiwali na sejm, który będzie obradował od 7 maja do 18 czerwca pod przewodnictwem w izbie referendarza koronnego Feliksa Kryskiego" (s. 227). Owszem monarcha zapewne już wówczas zamierzał poprzeć Kryskiego na godność marszałka poselskiego, ale żeby miał informować o tym szlachtę na pięć tygodni przed sejmem, to już gruba przesada, król nie mógł też znać dokładnej daty zakończenia obrad parlamentu.

Wreszcie ostatni z przytoczonych przykładów: duże zdziwienie czytającego wywołuje nazywanie Radziwiłłów na początku XVII w. separatystami litewskimi, a Jana Karola Chodkiewicza „federalistą” (s. 224).

Pomyłki występują również w bibliografii. Tak oto (s. 368) przypisano błędnie Markowi Ciarze autorstwo monografii o Weyherach, podczas gdy autor ma na imię Stefan. Z kolei z Haliny Michalak uczyniono A. Michalka (s. 383). Zastosowano ponadto dziwne skróty, zamiast KH dla „Kwartalnika Historycznego użyto „Kw. Hist.”, a zamiast PH dla „Przeglądu Historycznego” zastosowano „Prz. Hist.”.

Reasumując, w pracy Przemysława Szpaczyńskiego postawiono śmiałą tezę o mocarstwowych dążeniach Zygmunta III i usiłowano sprostować negatywny obraz króla występujący przeważnie w historiografii. Czy Autorowi udało się te cele osiągnąć? Odpowiedź nie jest jednoznaczna. Z pewnością przedstawiono wiele istotnych argumentów na poparcie tezy, że król nie prowadził polityki prohabsburskiej, ale że starał się relacje z domem cesarskim traktować instrumentalnie. Czy jednak udowodniono mocarstwowe zamierzenia, czy raczej przedstawiono politykę królewską jako reagującą na bieżące zagrożenia i starającą się wykorzystać pojawiające się szanse? Wreszcie kwestia negatywnego wizerunku monarchy istniejącego w historiografii. Został on już przez poprzedników P. Szpaczyńskiego w znacznym stopniu sprostowany. Autor posunął się

${ }^{30}$ Jan Herburt z Fulsztyna notowany jako chorąży lwowski od 27 VIII 1583 do września 1606 (następca znany od 1610) - Urzędnicy, t. 3, z. 1, nr 779 i 780.

31 Urzędnicy, t. 10, nr 898. 
do skrajnej idealizacji swego bohatera, a przez to wysiłki jego nie przyniosły takiego rezultatu, jaki był jego zamiarem. Przykładem może być kwestia cesji tronu. Gdyby poprzestano na przytoczeniu istotnych argumentów (a nie brak ich w monografii) podważających winę monarchy, efekt byłby osiągnięty. Autor jednak starał się zdjąć z barków Zygmunta III jakąkolwiek odpowiedzialność za hazardową grę z Habsburgami, a tego nie udało mu się osiągnąć.

\section{Streszczenie}

Artykuł recenzyjny dotyczy monografii Przemysława Szpaczyńskiego Mocarstwowe dążenia Zygmunta III w latach 1587-1618, Kraków 2013. Monarcha ten był władcą Polski w okresie 1587-1632 oraz władał Szwecją od 1592 do 1599 r., gdy został przez Szwedów zdetronizowany. Ocenie poddano przede wszystkim relacje króla z Habsburgami i opozycją wewnętrzną w latach 1587-1592. Autor przedstawił istotne argumenty na poparcie tezy, że król nie prowadził polityki prohabsburskiej, ale starał się relacje z domem cesarskim traktować instrumentalnie. Można mieć natomiast wątpliwości, czy udowodniono mocarstwowe zamierzenia Zygmunta III, czy raczej przedstawiono politykę królewską jako reakcję na bieżące zagrożenia, starającą się wykorzystać pojawiające się szanse. Autor koryguje negatywny wizerunek monarchy w historiografii, przy czym nie zawsze zauważa, że został on już w znacznym stopniu sprostowany.

\section{Sigismund III vis-à-vis the Habsburgs and Jan Zamoyski}

This review article discusses a monograph by Przemysław Szpaczyński (Mocarstwowe dażenia Zygmunta III w latach 1587-1618, Kraków 2013) about the foreign policy of King Sigismund III Vasa, the ruler of Poland in 1587-1632 and of Sweden from 1592 to 1599 , when he was dethroned by his Swedish subjects. The assessment encompasses primarily the king's relations with the Habsburgs and the domestic opposition in the years 1587-1592, with the author examining essential arguments supporting the thesis that Sigismund conducted an anti-Habsburg policy but attempted to treat contacts with the imperial house instrumentally. On the other hand, we may doubt whether the author of the monograph has actually proved that Sigismund intended to attain the status of a great power or whether he has rather shown that royal policy reacted to current threats and tried to benefit from available opportunities. The author seeks to correct the negative image of the monarch which he considers to be prevalent in historiography, although he has not always noticed that to a considerable extent it has already been corrected. 


\section{Bibliografia}

Chłapowski, Krzysztof, i in., oprac. Urzędnicy centralni i nadworni Polski XIV-XVIII. Spisy. Urzędnicy Dawnej Rzeczypospolitej XII-XVIII Wieku. Spisy, red. Antoni Gąsiorowski, t. 10. Kórnik: Wydawnictwo Biblioteka Kórnicka, 1992.

Leitsch, Walter. Das Leben am Hof König Sigismund III. von Polen. Wien: Verlag der Österreichischen Akademie der Wissenschaften, 2009.

Leitsch, Walter. Sigismund III. von Polen und Jan Zamoyski. Die Rolle Estlands in der Rivalität zwischen König und Hetman. Wien: Verlag der Österreichischen Akademie der Wissenschaften, 2006.

Lepszy, Kazimierz. Rzeczpospolita polska w dobie sejmu inkwizycyjnego. Kraków: Wydawnictwo Polskiej Akademii Umiejętności, 1939.

Lepszy, Kazimierz. Walka stronnictw w pierwszych latach panowania Zygmunta III. Kraków: Wydawnictwo Gebethner i Wolff, 1929.

Polak, Wojciech. O Kreml i Smoleńszczyznę. Polityka Rzeczypospolitej wobec Moskwy 16071612. Toruń: Wydawnictwo Naukowe Uniwersytetu Mikołaja Kopernika, 1995.

Przyboś, Kazimierz, oprac. Urzędnicy województwa ruskiego XIV-XVIII wieku. Spisy. Urzędnicy Dawnej Rzeczypospolitej XII-XVIII Wieku. Spisy, red. Antoni Gąsiorowski, t. 3, z. 1. Wrocław: Wydawnictwo Polskiej Akademii Nauk, 1987.

Szpaczyński, Przemysław. Mocarstwowe dążenia Zygmunta III w latach 1587-1618. Kraków: Universitas, 2013.

Wisner, Henryk. Zygmunt III Waza. Wyd. 2. Wrocław: Wydawnictwo Zakład Narodowy imienia Ossolińskich, 2006.

Biogram: prof. dr hab. Edward Opaliński - Instytut Historii PAN w Warszawie oraz Uniwersytet Jana Kochanowskiego w Kielcach, Filia w Piotrkowie Trybunalskim; zainteresowania: elity władzy, parlamentaryzm, kultura polityczna Rzeczypospolitej i Rzeszy (Brandenburgia, Meklemburgia); XVI-XVII w.; e.opalinski@gmail.com. 